\title{
A Educação e a Escola do Povo Umutina na Aldeia Umutina
}

\section{Education and School of the Umutina People in the Umutina Village}

DOI: 10.26512/interethnica.v22i1.20904

\author{
Eliane Boroponepa Monzilar \\ Universidade de Brasília - UnB \\ e-mail: elibmonzilar@gmail.com
}

Resumo: O presente artigo apresenta uma proposta de estudo dos processos históricos do contato do povo Umutina. Pensado desde a perspectiva antropológica, tem como foco e fio condutor a escola indígena e os processos educativos tradicionais e o não tradicional no contexto escolar. Tem como objetivo contribuir com as discussões sobre a educação escolar do povo Umutina. Apresenta uma descrição e análise dos impactos, avanços e ações que a comunidade Umutina consolidou para resistir enquanto indígenas e como trabalharam para manter viva e ainda principalmente reconstruir a cultura Umutina. Os dados foram obtidos por observação participante, fontes bibliográficas e arquivos. O trabalho privilegiará os relatos dos anciões, dos jovens estudantes e dos professores da escola Jula Paré. É um registro, contado pela própria indígena pesquisadora e deve contribuir com a comunidade e a juventude da aldeia e para o campo da antropologia, para quem se dedica a pensar a educação indígena.

Palavras-Chave: Antropologia, Umutina, Educação Escolar.

Abstract: This article presents a study of the historical processes of the contact of the Umutina people. Thought from the anthropological perspective, it has as its main focus the indigenous school and the traditional and non-traditional educational processes in the school context. It aims to contribute to the discussions about school education of the Umutina people. It presents a description and analysis of the impacts, advances and actions that the Umutina community consolidated to resist as natives and how they worked to keep alive and rebuild the Umutina culture. The data were obtained by participant observation and bibliographic sources and archives. The work will privilege the reports of the elders, the young students and the teachers of the Jula Paré school. It wants to contribute to the community, to the youth people of the village and to the field of anthropology, for those who dedicate themselves to thinking about indigenous education.

Keywords: Anthropology, Umutina, Schooling.

A presente pesquisa trata de uma proposta de estudo que está relacionado aos processos históricos do contato do povo Umutina, desde a perspectiva antropológica, tendo como foco e fio condutor a escola indígena e os processos educativos tradicionais e o não tradicional. Tem como objetivo contribuir com as discussões relacionadas à educação escolar do povo Umutina e nesse sentido 
busca apresentar uma descrição e análise dos impactos, avanços e ações que a comunidade Umutina consolidou, ao longo das últimas décadas, para resistir enquanto indígenas e como trabalharam para manter viva e ainda, principalmente, reconstruir a cultura tradicional Umutina.

O trabalho se dará a partir de relatos dos indígenas Umutina, dos anciãos, das anciãs, dos jovens, dos(as) professores(as) da escola de Educação Indígena Jula Paré. Os dados foram obtidos por meio da observação participante, fontes bibliográficas e pesquisas em arquivos, que complementarão a coleta de dados. Trata-se de um registro contado pela própria indígena pesquisadora e que vai contribuir com a comunidade e a juventude da aldeia e para o campo da antropologia, especialmente para quem se dedica a pensar a educação indígena.

Este texto mostra vivências que estão relacionadas com a escola, parte dessas vivências se referem a vivências pessoais, da autora. Também conta com diálogos mantidos com os anciãos da aldeia Umutina. No espaço da escola, há um diálogo que visa uma interação entre professores, estudantes, pais, liderança, anciãos e comunidade agregando fazeres culturais, ou seja, a escola se apresenta como lugar que conecta o fazer e o aprender o conhecimento, está relacionada com a preparação de festa tradicionais, realizadas em abril, bem como fomenta questões sobre a espiritualidade e também sobre como é a concepção da juventude de hoje comparada com a geração passada. É importante trazer o conhecimento dos anciãos para as crianças e para os jovens da aldeia e refletir sobre esses processos de aprendizagem, que foram construídos a partir da visão indígena, outra questão que interessa.

A escola Umutina conta com uma grade curricular ampla: além das áreas do conhecimento Linguagem, Matemática e da Natureza, temos os Saberes Tradicionais e dentro desse estão as disciplinas tecnologia indígena, práticas culturais, práticas agroecológica, língua materna e artes. Durante o percurso escolar, os estudantes Umutina desenvolvem trabalhos de revitalizar, isto é, partem da memória dos anciões, juntando elementos externos, filtrando coisas boas para agregar valores e agindo diante da história e produzindo a reafirmação da cultura. Assim, a escola é um caminho, um caminho não só para acesso ao mundo dos não indígenas, mas para transitar e conhecer também o conhecimento do universo indígena, uma forma de fortalecimento das práticas tradicionais.

No contexto escolar Umutina, o esforço da comunidade tem sido realizar um trabalho específico, político, que versa sobre um engajamento de professores indígenas, estudantes da escola Jula Paré e comunidade, onde todos incorporam a responsabilidade de fortalecer, valorizar, para ir contra a memória de educação para perdas. Para isso, foi imprescindível a formação de professores indígenas que, quando retornam, começam o diálogo com os anciãos.

Para se chegar a este ponto, vivemos um processo ou etapa que transcorreu, ao longo dos anos, com apoio das lideranças, do cacique e da comunidade. Os fatos que sucederam nesse processo são reveladores, iniciaram-se com a intensidade do debate sobre qual escola que queríamos. Percorremos questionamentos sobre como lidar com elementos externos nesse processo de aprendizagem; 
quais foram os avanços conquistados e almejados nesse contexto, quais gargalos referentes aos jovens que têm princípios e vontade diferentes; como atuar como professor indígena diante desse "caminho?". Esses elementos do saber/fazer Umutina estão reunidos, porque aprender não está separado da vivência, mas estão em conexão e sintonia com os modos de pensar e agir de ser Umutina.

Os Umutina são um povo indígena do tronco linguístico Macro Jê da família Bororo, habitantes da região central de Mato Grosso, Brasil. Atualmente, vivem no Território Indígena Umutina, na aldeia Umutina, nas margens de um importante rio brasileiro, o Paraguai (Laripô), a pouco menos de $150 \mathrm{~km}$ da capital do Estado de Mato Grosso, Cuiabá.

Conforme escrevi em Monzilar, 2018, as primeiras informações a respeito dos Umutina são de Ricardo Franco de Almeida Serra, em "Extracto da descripção geografia da Província de Mato Grosso" produzido em 1797, segundo Schutz (1962). Têm-se dados da localização do povo Umutina, nas margens do rio dos Bugres, afluente do Alto Rio Paraguai. Conforme informação de Augusto Leverger (apud SCHUTZ, 1962:76):

"3 léguas mais baixo, entra pela margem direta, um riacho de canoa a que alguns chamam Rio Branco, outro Rios dos Bugres ou dos barbados e também Tapirapoan. Nas cabeceiras deste riacho, está o aldeamento dos índios barbados. Seu numero anda por 40o. Sustentam-se de caça, da pesca, dos frutos espontâneos do solo e de milho, mandioca, batata e carás que plantam, cultivando a terra com instrumentos feitos de pedra, e de madeira de cerne. Vivem em paz com outras nações indígenas. Posto que pouco distante das nossas povoações, nunca tiveram nem procuraram ter relações comnosco. Descem às vezes até a margem do Paraguai. Tem sucedido atacarem canoas que iam do Diamantino para Villa Maria, e se não nos hostilizam mais frequentemente é de medo das nossas armas”.

Neste artigo, descrevo os processos históricos do contato do Povo Umutina com ênfase nos processos educativos tradicionais e não tradicionais. Apresento a narrativa de origem, os relatos de vivências dos saberes e fazeres e o contexto do território indígena, temas trabalhados na minha dissertação de mestrado (Monzilar, 2012). Esse trabalho foi desenvolvido com a participação dos jovens estudantes do Ensino Médio da Escola de Educação Indígena Jula Paré, das mulheres e homens, das lideranças e anciãos da aldeia, que são detentores de conhecimentos tradicionais. Na interação com a discussão da escola, descrevo o modo de acontecer dos eventos relacionados à pesca, roça, ritual da pesca e trançados. Por fim, analiso como o povo Umutina está se adaptando a novos modos de vida impostos por mudanças territoriais, culturais e principalmente processos educacionais. 


\section{A História do Povo Umutina}

Vou contar o mito do povo Umutina sobre a origem da vida. Começa assim:

"Antigamente, Haipuku (Deus) vivia sozinho no mundo e para sua companhia, foi fazer vários experimentos.

Primeiro então, ele juntou bacava do campo, fruta macho e fruta fêmea, vai juntando, juntando e juntando e deixa ali. À noite Haipuku, fica assustado com conversas e, quando vai verificar, as frutas tinham virado gente. Haipuku fica muito alegre, satisfeito com os companheiros.

Haipuku foi experimentar fruta de figueira de folha larga, juntou, juntou até dar um comprimento, deixando ali de lado. À noite, ouviu conversa de gente e foi ver, a fruta de figueira da folha larga tinha virado gente.

Então ele já tinha muita gente. Experimentou novamente juntar fruta da bacava do mato, juntou, juntou e saiu gente de cabelo comprido, dois homens e duas mulheres, dois casais.

Para aumentar mais pessoas experimentou com mel de tatá. Saiu um casal com a cabeça pelada. Haipuku já tinha bastante povo, muito povo, criou barriga de perna por dois lados, ficou apavorado e procurou um pé de figueira, então racharam as pernas e nasceram quatro crianças, dois meninos e duas meninas. As crianças não quiseram ir com ele pra sua casa.

Haipuku mandou fazer um ametá para as meninas e um arco para os meninos, aos dois civilizados. A menina civilizada não ajeitou com o ametá e o menino civilizado não ajeitou com o arco. Eles não quiseram ir com ele acompanhar na sua casa. Então o menino e a menina indígena ajeitou com o ametá e o arco.

Haipuku falou para eles morarem com ele, em sua casa, mas eles não quiseram ir. Então, Haipuku disse: "Para onde vocês vão?". Eles disseram: "os civilizados, para a direção do Rio Paraguai, para baixo e as crianças indígenas, em direção ao Rio Bugre para cima”. Assim surgiu a origem da vida do povo Umutina, Haipuku fez esses experimentos com frutas de bacava e a fruta da figueira, e assim criou companheiros para ele no mundo" ( Schultz, 1960).

Essa narrativa é contada pelas pessoas mais velhas da aldeia e está registrada nos relatos que Arold Schultz escreveu sobre o povo. Schultz foi um etnógrafo que passou um período na aldeia e obteve essa informação com um ancião da época. Hoje essa narrativa é contada para as crianças e para os jovens, como originou a vida para o povo Umutina. 
Conforme escrito em Souza; Monzilar (2016), ao contarem o mesmo mito de origem, os Umutina mestiços, filhos de casamentos interétnicos e dos não indígenas, constroem um novo laço identitário, recriando uma origem comum com os sobreviventes Umutina. Esses laços concretizam também, a partir dos processos de territorialização, um espaço comum, permitindo a reorganização da identidade desde o território.

Podem ser destacadas no mito questões importantes relacionadas ao contexto da história do contato do povo Umutina como:

- o espaço geográfico que situa a história no território atual, informa os rios Laripô (Paraguai) e Xopô (Bugres) o mesmo que cerca o atual território Umutina;

- a organização social dos Umutina;

- a espiritualidade indígena e, a origem da vida, que se relacionam a diferentes espécies e variedades vegetais nativas, mel e o corpo do ancestral;

- a relação com os não indígenas e os indígenas;

Esses pontos serão contextualizados em sequência para melhor compreensão do processo histórico do povo.

Conforme escrevi em Monzilar (2012), o processo de pacificação dos Umutina se deu em várias etapas. O início se deu quando Marechal Rondon mandou instalar um posto de atração em 1911. A partir do contato, houve conflitos entre os indígenas e não indígenas, em seguida, as lastimáveis epidemias de sarampo, tuberculose e pneumonia fizeram órfãos principalmente as crianças, mas atingiu os velhos, matando-os. A permanência do contato contribui para a perda da população e de traços culturais particulares.

No entanto, destaco dois pontos que fazem referência à história da origem do povo: relação de enfrentamento dos colonizadores e os indígenas, conflitos, e as doenças trazidas pelos homens brancos, que causaram morte e danos aos hábitos e saberes dos Umutina.

\section{Relatos e Vivências - Memória do Contato Posto Velho/ Aldeia Humaitá}

Conforme em Monzilar e Monzilar (2006) obtivemos relatos do senhor Adão Táxi, chefe do posto do Serviço de Proteção ao Índio (SPI) que esteve na frente da expedição na época do contato do povo Umutina. Disse que, primeiro, eles reuniram em "Posto Velho" a primeira aldeia que eles estiveram com índios. Para "seduzir", ou seja, para se aproximarem dos índios deixavam alimentos como arroz, sal e entre outros e os instrumentos como faca, fação, machado, deixavam no caminho. E ficavam de longe observando os índios se aproximando para pegar os objetos, foram várias vezes que ocorreu essa forma de 
aproximação com os índios Umutina. Um dos primeiros índios que vieram se juntar a eles foram os índios chamados Kupo e Apo que os ajudaram a aproximar dos outros indígenas.

Naquela época, de acordo com Monzilar e Monzilar (2006), foi muito difícil o contato, principalmente por causa da língua, e os índios eram muitos "bravos", resistiram. A educação na época do SPI visava o ensino do português e o extermínio da língua indígena para fins de dominação. Atualmente, quem não sabe a língua indígena na escola Umutina descobre que ser indígena não se resume a uma língua e que, portanto, terem exterminado a língua Umutina não resultou no extermínio do povo Umutina. Sem língua, os Umutina persistiram e continuam existindo como Umutina por conta de outros elementos. E esses elementos são enfatizados nessa forma de educação defendida atualmente na escola Umutina.

Ao utilizar a técnica de colocar alimentos e instrumentos de ferramentas por várias vezes, os não-indígenas conseguiram se aproximar dos indígenas. Nesta primeira aldeia, "Posto Velho", que ficava próxima a margem do rio Bugres, os índios ficaram lá por dois a três anos e em seguida foram para outro lugar mais longe chamado "Humaitá". Esse local era mais distante da cidade e ficava à margem do rio Paraguai, e era mais alto. Lá os índios foram viver juntos com não indígenas, aderiram à vida cotidiana desses últimos, trabalhavam na roça e aprenderam a serem bons trabalhadores, viviam como os colonizadores.

Contam os mais velhos que os primeiros povos que vieram para cá, viver com eles, foram os Paresi e os Nambikwara. Esses foram trazidos por brancos que estavam à frente da expedição do Marechal Cândido Rondon. Havia um movimento intenso e de deslocamento dos povos indígenas na região, deslocamentos forçados.

Há duas versões sobre a vinda desses indígenas: os mais velhos dizem que era uma forma de ajudar a assegurar o território dos Umutina, visto que, na época, os Umutina eram poucos. Outra versão defende que esses indígenas foram trazidos como forma de castigo, quando faziam algo errado, eram transferidos da sua aldeia para outra aldeia, para serem reeducados.

Eles diziam que foi um grande choque cultural, que desestruturou a forma de vida dos indígenas, e deu origem a conflitos entre os índios e não indígenas. Os Paresi não se adaptaram a viver num lugar fora de sua origem e muitas vezes alguns fugiam para regressar a sua terra, sendo perseguidos pelos os funcionários do Serviço de Proteção ao Índio. (SPI) Alguns Paresi e Nambikwara ficaram no território e tentaram viver e conviver juntos com os Umutina, dentre os quais podemos citar: Antônio Paresi, Pedro, Valdemar, Emiliano, Floriano, Tomé, Isabel, Jorge, Ana, Alaide, Alice, Rita, Joventina, Maria entre outros.

Houve um período muito tenso, marcado por confrontos, resistências, pois os indígenas que aqui vieram não queriam de forma nenhuma se misturar. Essas gerações de jovens, que passaram a residir no território, se casaram entre eles e formaram novas famílias. Essas famílias Paresi e Nambikwara contribuíram 
muito neste processo histórico do povo Umutina. Mais ou menos da mesma maneira, posteriormente, vieram outros povos para a atual região da aldeia. Ao longo do tempo, aconteceram casamento interétnicos e nos últimos anos tem tido uma elevação de casamento entre índio e não indígena.

Dona Carminda Monzilar, descendente de Paresi, seus pais são Paresi e Nambikwara, tem cinquenta anos, mora na aldeia Umutina, contou como era antigamente o casamento:

\begin{abstract}
"A jovem namorava com o rapaz, se o pai gostava do rapaz, logo fazia casar. Antes, os pais que escolhia o casamento para o filho e a filha. Quando a criança nasce já estava comprometido e quando cresce aos nove anos o pai já entregava para o rapaz. Quando acontecia o casamento a mulher vem para a casa dos pais do rapaz $e$ quando é o rapaz fica na casa do sogro, às vezes morava separado ou morava junto com os pais. Tanto a menina quanto o rapaz quando casam são considerados como filho ou filha mais um chegando à família. Para conceber uma criança tinha que ter o casamento, por isso casamento é importante. No casamento havia uma afeição recíproca entre o homem e a mulher, principalmente na relação sexual, as mulheres geralmente demorava engravidar".
\end{abstract}

Dona Carminda quando casou foi o pai quem escolheu o rapaz para casar com ela, então conversou e aceitou, em seguida aconteceu o casamento, ela ficou na casa do seu pai Jorge, até fazer uma casa para morar separado e quando já tinha construído a casa foi para a sua nova moradia.

Os Paresi não queriam misturar, eles diziam que os seus filhos tinham que casar com os seus parentes mesmo. Eles não aceitavam, mas, não teve jeito e tiveram que aceitar. Eles queriam que casassem com os Paresi. Os homens são o chefe da casa e da família na cultura do Paresi e dos Umutina.

Carminda ressaltou:

\begin{abstract}
"Naquela época era proibido casar com não indígena. Quando o filho dela casou com uma não indígena aos 18 anos de idade, ela teve que pedir permissão para o cacique o senhor Joaquim diante de uma reunião, então o cacique aceitou, pois, ela tinha trabalhado a dez anos na aldeia”.
\end{abstract}

\title{
O Território e Cultura Umutina
}

O território Indígena Umutina está localizado no centro-oeste do Estado de Mato Grosso, a 15 quilômetros do município de Barra do Bugres. O Território 
tem o formato de uma ilha fluvial, de 28.120 hectares, protegido à direita pelo Rio Xopô (Bugres) e à esquerda pelo Rio Laripô (Paraguai).

\author{
Mapa 01 \\ Terra Indígena Umutina
}

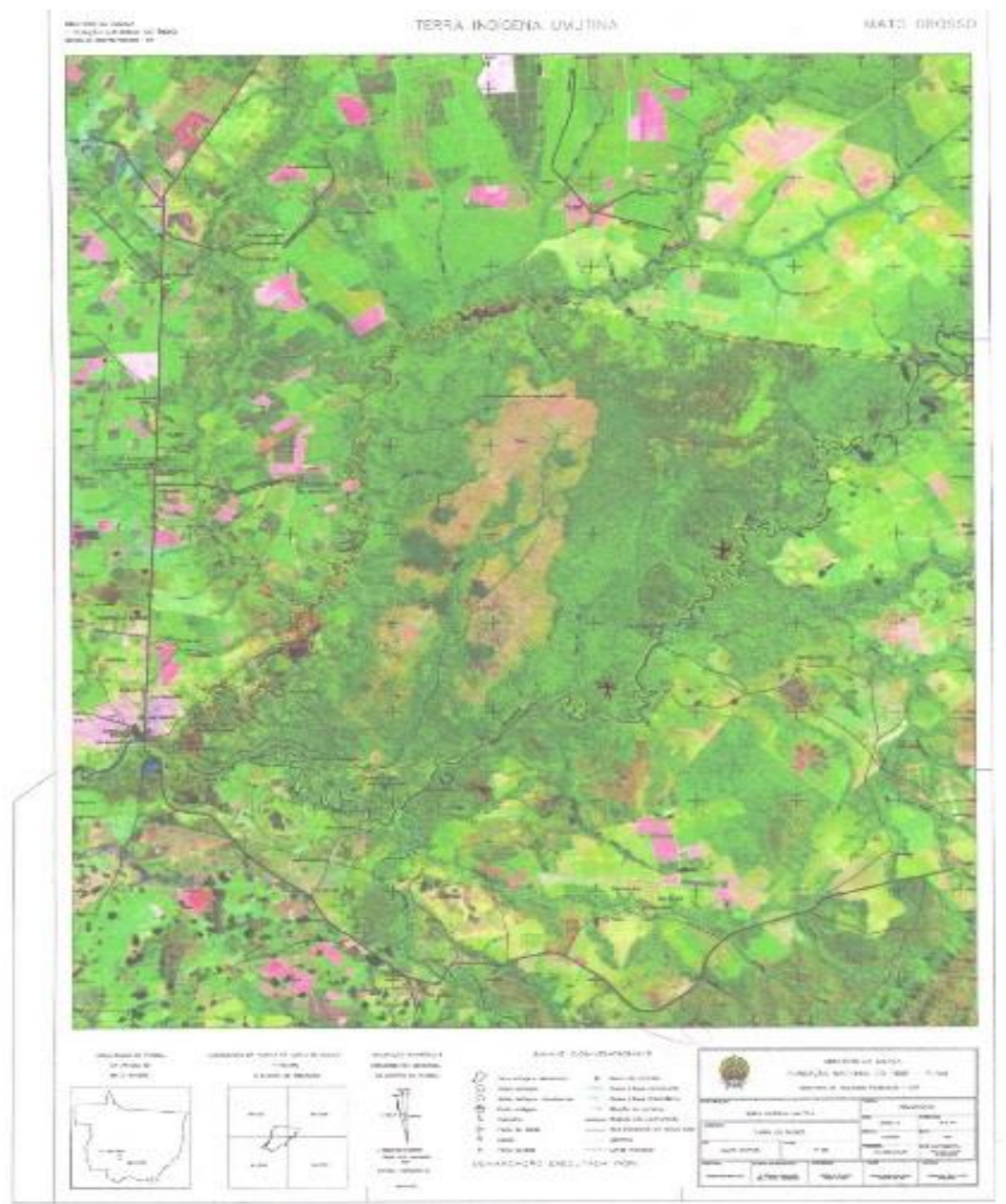

Fonte: ARQUIVO FUNAI, 2013.

No entorno há propriedades particulares com plantação de cana de açúcar e criação extensiva de gado. Em uma localidade chamada Alto Paraguai, está a nascente do Rio Laripô (Paraguai), há muito tempo existiu um garimpo, hoje desativado.

A aldeia Umutina é uma aldeia multiétnica, convivem vários povos: Paresí, Nambikwara, Bororo, Bakairi, Irantxe, Kayabi, Terena, Umutina e recentemente Chiquitano, há casamentos interétnicos e um grande número de casamentos entre indígenas e não indígenas entre os moradores, porém todos se reconhecem como Umutina.

Conforme as informações etnográficas e a memórias dos anciãos, dizem que os Umutina dominavam um território que compreendia a região dos rios Sepotuba, Bugres e Paraguai, onde praticavam a caça e a pesca. Com a chegada dos não indígenas ao Mato Grosso, o povo Umutina, acabou perdendo essa liberdade, causando conflitos e mortes de parte a parte. Nesse período em que a política do 
governo era exterminar os indígenas e expandir a exploração no interior da região, principalmente pela poaia e a seringa, começam confrontos e conflitos entre os Umutina e o não indígenas.

Essa atividade externa são trabalhos que interferem nessa relação do entorno do território Umutina como destruições, impactos do ambiente, bem com das pessoas que interagem neste espaço, mostra de como o colonizador e os indígenas se relacionam no território. Essas atividades produtivas, de larga escala, têm implicado na degradação do meio ambiente. Sobretudo as queimadas, provenientes das plantações de cana de açúcar, e as pastagens plantadas para o gado, trouxeram grandes prejuízos, atingindo o território Umutina por meio das queimadas, da poluição dos rios e o intenso desmatamento na região (MONZILAR, 2012, p.14).

Desde criança, eu ouvia dos meus pais e da minha irmã histórias sobre a vivência na roça. Quando ela era criança, a roça era feita distante da casa, para onde eles iam todos os dias trabalhar. Primeiro, era escolhido um lugar para fazer o roçado, depois derrubavam as matas com machado e faziam a queimadas, o que acontecia na estação seca. Em seguida, faziam as plantações que era antes das primeiras chuvas. Os homens passavam a semana inteira na roça, trabalhando, mas na época da colheita, toda a família participava principalmente na época da colheita da melancia. Eles plantavam arroz, milho, cana de açúcar, banana, mandioca, melancia, abóbora entre outros.

Lembro-me que um dia fui à roça dos meus avós e para chegar lá caminhávamos uma longa distância. Era a maior alegria quando chegava para pegar e chupar melancia na roça, e ao retornar fazíamos o mesmo percurso carregando as melancias no saco. Era muito bom, eu adorava ir, íamos todos os meus primos, as minhas irmãs, era uma época de muita fartura.

O senhor Adilson, morador da aldeia Umutina, destacou que na época do povo antigo faziam roça de toco e plantavam muita coisa como arroz, banana, batata, cana e outros. Quando chegava à época de festa, tinha muita fartura. Ele falou da importância do trabalho na roça, plantar e colher os alimentos para as famílias. Segundo ele, hoje, os alimentos estão muito caro e por isso tem que fazer a roça. Em julho, já é tempo de fazer a roça. Certa ocasião, encontrei eles roçando no antigo curral para fazer a roça, fazendo mutirão, quando seria plantada banana, milho, cana, e na capoeira antiga iriam plantar a mandioca (Entrevista realizada 28/07/2015).

Apesar da destruição no entorno, a TI Umutina se encontra bastante preservada 1 , pois o povo faz a roça de toco, planta e colhe, utilizando as técnicas e conhecimento tradicionais indígenas. Com base nesse sistema, são produzidos alimentos para a subsistência familiar. Além da agricultura, a pesca é parte importante da alimentação e a principal fonte de renda das famílias.

\footnotetext{
${ }_{1}$ De acordo com dados do Instituto Socioambiental - ISA (2012), entre 2000 e 2009 a área desmatada na TI Umutina foi de apenas 2.217 ha, da área total de 28.120 ha dessa Terra Indígena. Em Contraposição, o desmatamento no entrono dela é bastante intenso, de modo que a TI Umutina constui-se na maior área preservada no município de Barra do Bugres
} 
Como escrevi em Monzilar (2012), com a chegada das frentes colonizadoras no estado de Mato Grosso, a partir do século XIX, os Umutina acabaram perdendo a liberdade e passaram a enfrentar longo período de conflitos com as frentes que subiam os afluentes do Paraguai, explorando a poaia, seringa, ouro e novas terras. Os Umutina se deslocaram, subindo o rio Laripô (Paraguai), cedendo à pressão, com o avanço da colonização, foram obrigados a recuar, chegando onde hoje é a atual aldeia Umutina. Mas os dados históricos e os mitos Umutina revelam que a bacia do rio Paraguai foi território tradicional do povo.

Segundo o padre Salesiano Nicolau Baclarioti, em 1898 (OPAN, s.d), era a intenção do Governo do Mato Grosso organizar uma expedição de extermínio contra esses indígenas dados à resistência, que se opunham à penetração de não indígenas em suas terras. Mas foi somente após um ano da criação do Serviço de Proteção ao Índio (SPI), 1911, que se consolidou o contato com o povo Umutina, em 1912.

Em Monzilar, Monzilar (2006) obtivemos relatos do antigo chefe do posto do SPI, senhor Adão Táxi, nascido em 1933, pertencente à família do Sr. Epifânio, de que a pacificação com os Umutina não foi fácil. O processo de "pacificação" aconteceu durante alguns anos e a tática usada pelos não indígenas foi o plantio de roças na margem esquerda do rio Bugres, para atrair os indígenas. Enquanto não era chegada a hora da colheita, eles colocavam na roça produtos alimentícios como o arroz, açúcar, feijão, além de ferramentas como enxada, faca, facão e outros para oferecer aos indígenas. $O$ não indígena que fez o primeiro contato foi Severiano Godofredo de Alburquerque, era o chefe da expedição do contato, mas quem passou a dar continuidade do processo foi Epifânio Ribeiro Táxi, com seu irmão Benedito Ribeiro Táxi e outros, sendo doze homens no total. (entrevista realizada em setembro de 2005).

Segundo relato de Adão Táxi (MONZILAR; MONZILAR, 2006), o primeiro contato do SPI com os Umutina aconteceu no Posto Velho - a primeira aldeia que reuniu os indígenas. Ficaram ali de um a dois anos, à margem esquerda do rio Bugres. O contato decorreu a pedido dos poaeiros, que disseram ao Cândido Rondon tomasse providências, pois os indígenas estavam matando o não indígena na região. Esse diálogo teria ocorrido quando Cândido Marechal Mariano Rondon passava pela região para a construção de um ramal da linha telegráfica em Afonso, hoje cidade São Afonso.

Em Monzilar (2012) constato que a princípio o povo Umutina era conhecido pelos não indígenas como "barbados" pelo fato de usarem longas barbas. As mulheres deixavam os cabelos crescerem para que os homens os cortassem. Com os cabelos das mulheres confeccionavam os colares para o uso masculino. As mulheres e crianças andavam muito ornamentadas. Tanto as mulheres quanto as meninas tinham o corpo despido somente da cintura para cima, coberto por muitos colares de dentes de animais e grandes brincos de pena coloridas. De acordo com Schultz (1960) os Umutina eram tecelões e ceramistas e desenvolveram o trançado. A base alimentar era o milho com o qual faziam mingaus, e beiju etc. Cultivavam mandioca, feijão fava e pimenta. $\mathrm{O}$ alimento mais importante depois da lavoura é a caça e o pescado. $\mathrm{O}$ tabaco e bebidas fermentadas não eram conhecidos. 
Com o contato e o convívio com os colonizadores, conforme afirmo em Monzilar (2012), os Umutina passaram a assimilar e se socializar à cultura dos wace (branco), a viver em um regime bastante distinto do cotidiano da maloca e por imposição de um chefe de posto, Otaviano Calmon, sob ameaças e castigos, foram proibidos de falarem a língua materna e de realizarem suas festas e rituais. Trouxeram doenças que provocaram muitas mortes, principalmente entre as crianças e velhos. Fortes epidemias de sarampo, tuberculose e pneumonia fizeram órfãos entre as crianças, além de deixarem jovens solteiros enfermos na grande maioria das malocas.

Foi nesse período que uma política do governo federal, via SPI trouxe para o território Umutina famílias de outros povos indígenas. Neste contexto, foram várias intenções, como assegurar e proteger o território Umutina e deportar indígenas que deveriam sofrer punições e eram transferidos, sendo reeducados.

$\mathrm{Na}$ década de 40, contavam-se 50 Umutina no posto e 23 em 3 malocas na mata, que resistiram aos esforços de atração do posto. No posto, os indígenas de diferentes povos constituíam uma nova comunidade com leis e normas alheias a cada um dos grupos ali apresentados, o que desencadeou um estado de conflitos entre eles. Eram várias culturas, em estágios diferenciados de contato, o que fez com que nos anos 1930 e 1970 a população do Posto Indígena Fraternidade vivenciasse o desencanto e a desestruturação das formas originais de suas culturas (Umutina, Paresí e Nambikwara), (MONZILAR, 2012).

Na década de 1980, a população do Posto Indígena Umutina era de 77 pessoas, sendo 36 Umutina descendentes de órfãos recolhido pela sede do posto e de alguns Umutina independentes. Os demais eram Paresi, Kayabi e Nambikwara que foram trazidos pelo Serviço de Proteção ao Índio (SPI). ${ }^{2}$

Nos últimos anos, conforme o senso realizado na aldeia, ocorreu um significativo aumento demográfico entre os Umutina. Em 2012 os dados apontavam uma população em torno de 480 pessoas 3 , sendo a maioria jovens e crianças. Atualmente, os grupos que têm estudado demografia na escola e na aldeia usando os dados da saúde e as informações das famílias sobre quem vive fora da aldeia, afirmam que há em torno de 400 pessoas vivendo na aldeia e 100 pessoas nas cidades próximas.

Esses dados têm uma relevância significativa, pois a população da aldeia Umutina está aumentando, devido aos casamentos entre as etnias de jovens que estão construindo famílias, porém, apesar da violência histórica da colonização a que foram submetidos pela política do governo, esse dado mostra outro percurso que estão trilhando e reorganizando, a bravura e coragem dos Umutina.

\footnotetext{
2 Recenseamento realizado por A. J. Jesus (Relatório $\mathrm{n}^{\mathrm{o}}$ 09/Posto Indígena umutina - FUNAI, 1980).

3 De acordo com levantamento realizado pelo Prof. Jairton Kupudonepá, em conjunto com estudante do Ensino Médio da Escola Jula Paré, na aldeia Umutina, em 2012.
} 
As famílias vêm aumentando e há uma grande preocupação para que as futuras gerações possam ter uma vida saudável. Para as famílias Umutina a terra é fundamental para manter viva a cultura de seu povo, é através dos recursos naturais existentes que se faz a sobrevivência material e simbólica dos Umutina.

Conforme escrevi em Monzilar (2012) ao analisar os fatos que ocorreram na história dos Umutina, há lastimável tragédia do contato com a sociedade colonizadora, o povo Umutina conquistou grande avanço, teve sabedoria e estratégias para sobreviver. Hoje a população vem aumentando, totalizando cerca de 480 pessoas. Este aumento é significativo para um povo que no passado teve seu número reduzido para apenas 23 pessoas. E relevante enfatizar que essas pessoas tiveram papel imprescindível no processo histórico para a continuidade de novas gerações dos Umutina.

\section{Mudanças Sociais - Modos de Viver e Agir}

De acordo com Monzilar (2012), a convivência com a sociedade envolvente implicou em grandes mudanças para o povo Umutina, que, nesta conjuntura, está se organizando e ressignificando a cultura, de modo a manter o sustento para viver e garantir a sustentabilidade nas dimensões social, territorial e ambiental. A comunidade e os professores Umutina estão buscando, na escola, a revitalização da cultura, do que foi proibido no passado. Embora não sejam falantes da língua nativa, estão, em conjunto, incentivando crianças e jovens a praticar a cultura dos Umutina - um processo complexo, já que na aldeia vivem famílias descendentes de outros povos indígenas.

Monzilar (2012) constata que a revitalização da cultura tem se mostrado fundamental para todos os moradores, que entendem que, se a cultura estiver sendo repassada para as novas gerações, os jovens se tornarão conhecedores e protagonistas da sua história e de seus valores. É um rico trabalho, cheio de significado para os Umutina e, por isso, a comunidade tem participado e acreditado na eficiência da escola como espaço para revitalização de suas práticas culturais.

A revitalização da cultura é relevante, pois é um trabalho que vem sendo moldado e dialogado num processo contínuo de luta e fortalecimento, repassado para as crianças e jovens de modo que eles se tornem conhecedores dos saberes e fazeres. Esse contexto de incentivo à escola como espaço onde também pode acontecer revitalização da cultura se consolida na década de 1990, depois de um percurso marcado por movimentos constantes, embates, resistência, conquistas e desafios.

Reporto-me a um relato que me foi contado pela minha tia Carminda, sobre a primeira infância e a transmissão de aprendizagem numa determinada época, e como ela vê esse processo agora no presente.

Então ela disse: 
"Nós brincava quando tinha a lua, brincava de rouba bandeira, de roda, ficava cantando altas horas à noite, os pais sentava na frente da casa e contava histórias, as brincadeiras eram no dia de lua cheia, ficava claro, a lua era nossa energia de antigamente. $O$ divertimento era a festa, o pai e a mãe levavam as meninas nas festas, quando queria vir embora trazia todos juntos. A festa era somente na lamparina, vela, fazia fogueira, era bem animado. Era no violão, sanfona, pandeiro, bombo, gaze era o instrumento de festa que dançavam, os guris tocava esse instrumentos"(Entrevista realizada 06/11/2015).

Ela continuava contando que a família trabalhava na roça e desde pequenas as crianças acompanhavam os seus pais na roça. Durante a semana, após saírem da escola iam para a roça e iam pescar. Tinha só final de semana para divertir. Os meninos iam para a roça carpir e plantar. As meninas ficavam em casa para ajudar a mãe nos afazeres de casa. Quando era época da colheita todos iam ajudar tanto menino e menina.

Nesse contexto, para os Umutina, o trabalho que as crianças realizavam era acompanhar os pais, fazia parte do aprendizado, algo positivo na construção do saber, do conhecimento da vida para a vida. Eles aprendiam todo o manejo de lidar com a roça, a escolha do lugar, a roçada, o plantio e a colheita.

As crianças respeitavam os pais, quando mandavam fazer algo, tinha que ser feito, se não fizessem, eram punidos com castigos, muito rígidos. As crianças com doze anos já sabiam trabalhar, seguiam a regra que os pais davam.

Segundo a minha tia Carminda (06/11/2015), a criação da criança era bem diferente. Na escola não havia tecnologia como hoje, houve mudanças no comportamento das meninas e dos meninos. Antes as crianças faziam leituras, e, ainda, permaneciam os valores familiares de respeito e obediência, alguns jovens se rebelavam com os pais.

Para minha tia, isso acontecia devido à televisão e o celular que influencia esse comportamento. Ela percebeu essa mudança de comportamento quando esteve na escola, durante a semana cultural, foi feito uma oficina para ensinar os estudantes adolescentes a confeccionar o cesto. Notou o pouco interesse de alguns, que só ficavam no celular, e ficou muito amuada diante do comportamento desses adolescentes. Houve, por outro lado, os que ficaram atentos e aprenderam como fazer o cesto quadrado e redondo.

Para senhor Adilson, (28/01/2015), hoje:

"A situação é muito complexa com a chegada da tecnologia na aldeia, principalmente o meio de comunicação, o celular, tenho observado que os jovens ficam encantados e deixando muitas vezes de conversar com os mais velhos. Esse 
instrumento comunicativo tem duas questões para refletir, tem a sua vantagem que é positiva e por outro lado tem prejudicado, ou seja, é negativo, porém a juventude gosta".

Conforme Monzilar (2012), muitos dos jovens já se pintam e cantam sem nenhum tipo de receio e isso é muito importante, até os adultos estão participando e valorizando a cultura. Portanto, pode-se notar um grande avanço.

Desde a década de 1990, os professores Umutina vêm desenvolvendo trabalho que tem fortalecido as práticas culturais da comunidade, como a festa tradicional que é realizada no período de mês de abril, a semana cultural. Na festa tradicional são feitos os preparativos da dança, a pintura corporal, os cantos, as comidas típicas: beiju, a xixa, peixe assado e a caça, confecção de trançados de diferentes formas e, no final, a apresentação das danças: Mixinosê, Lorunó, Yuri, Katamã, Andorinha, Boiká, entre outros, e há participação de toda comunidade.

A juventude e as crianças já se pintam cotidianamente, cantam na língua materna sem receio, os adultos estão envolvidos ativamente e valorizando a cultura. A língua materna tornou-se matéria obrigatória no currículo da escola e está sendo repassada através dos anciãos que, ainda, estão vivos.

No contexto escolar, são ensinados para as crianças vocabulário da língua Umutina, essa experiência tem sido bem sucedida, pois as crianças já falam e conhecem as palavras na língua. Os professores indígenas têm tido um papel importante nesse trabalho que está sendo desenvolvido, principalmente os da área de linguagem que se formaram no curso (Projeto do Terceiro Grau Indígena) ensinam a produzir frases e até textos na língua materna. A escola movida pelos professores indígenas conecta "fazeres culturais", busca relacionar os diversos universos que o contato promoveu, estrutura-se nos ensinamentos dos anciãos ao mesmo tempo em que transita pelo mundo dos brancos, tão inevitável e necessário conhecer para o ativismo político do povo Umutina.

\section{REFERÊNCIAS}

BRASIL. Lei de Diretrizes e Bases da Educação Nacional. Lei n. 9.394, de 20 de dezembro de 1996. Presidência da República, 1996.

CRUZ, M. C. ; COREZOMAE, M. M. A Língua Umutina na Escola Indígena Jula Paré: Ensino e Revitalização Linguística.

DIONES, H. Pesquisa-Ação para o Desenvolvimento Local. Brasília: Liber Livro, 2007.

GRUPIONI. Luís Donisete Benzi. A escola e a comunidade indígena. [s. 1.], [s. d.] (mimeo). 
HUARE, D. T. ; SILVA, M. A. O. Língua Umutina: Repreensão e Memória. Revista de Estudos Acadêmicos de Letras, Unemat Editora, ed. 07, $\mathrm{n}^{0}$ 02. Dez. 2014 .

ISA. De olho nas Terras Indígenas no Brasil: Terra Indígena Umutina. Disponível em: http://ti.socioambiental.org/pt-br/\#!/pt-br/terrasindigenas/3889. Acesso em 23 de novembro de 2012.

JANUÁRIO, Elias et al. Uma proposta de integração entre a pós-graduação em Ciências Ambientais e a Aldeia Umutina in Cadernos de Educação Escolar Indígena. vol. 8, n. 1. Cáceres: UNEMAT, 2010, pp. 93-106.

MELLO, Nathalia. O Silêncio- Narrativa dos Jovens Umutina Balotipone/ Barra do Bugres, MT, Brasil. Performatus, ano 2, nº 7, nov 2013.

Ministério da Justiça. Fundação Nacional do Índio. Diretoria de Assuntos Fundiários (DAF). Imagem de Satélite da Terra Indígena Umutina - MT. [s. d.]

MONZILAR, Edna. Alimentação do Povo Umutina Antes e Depois do Contato. Trabalho de Conclusão de Curso (Pós-Graduação em Educação Escolar Indígena), 2010.

MONZILAR, Edna; MONZILAR, Eliane Boroponepá. A mudança do Povo Umutina da Aldeia Umaitá para a Aldeia Umutina. Trabalho de Conclusão de Curso (Graduação em Licenciatura em Ciências Sociais) - Projeto de Formação de Professores Indígenas $3^{\circ}$ Grau Indígena. Universidade do Estado de Mato Grosso - UNEMAT, Barra do Bugres, 2006.

MONZILAR, Eliane Boroponepa. Educação Escolar Indígena e o Processo de Demarcação e Proteção Do Território Umutina. Trabalho de Conclusão de Curso (Pós- Graduação Educação Escolar Indígena), 2010.

- Território Umutina: vivências e sustentabilidade. Dissertação de Mestrado. Centro de Desenvolvimento Sustentável, Universidade de Brasília, Brasília, 2012.

- Território Umutina: Vivências e Sustentabilidade. R. Tecnol. Soc., Curitiba, v. 14, n. 34, p. 122-143, out./dez. 2018.

OLIVEIRA, C. E. Universo a Poaia e seu Patrimônio Cultural: marcas do tempo de Rondon e da Coluna Prestes. XXVII Simpósio Nacional de História. Conhecimento Histórico e Diálogo Social, Natal- RN, 2013.

SCHMIDT, Max. Los Barbados os Umutinas em Mato Grosso in Revista de la Sociedad Científica Del Paraguay, n. 5, 1941, p. 1-51.

SCHULTZ, Harald. Vinte e três índios resistem à Civilização. São Paulo: Melhoramentos, 1953. 
- Informações etnográficas sobre os Umutina in Revista do Museu Paulista, Nova Série, n. 13, p. 75-313, 1962.

SOUZA, H.C.; MONZILAR, E. B. A Flecha do Tempo não Segue um Rumo Pré Determinado. Trabalho apresentado no $24^{\circ}$ Seminário de Educação-SEMIEDU, 2016. Cuiabá - MT. 